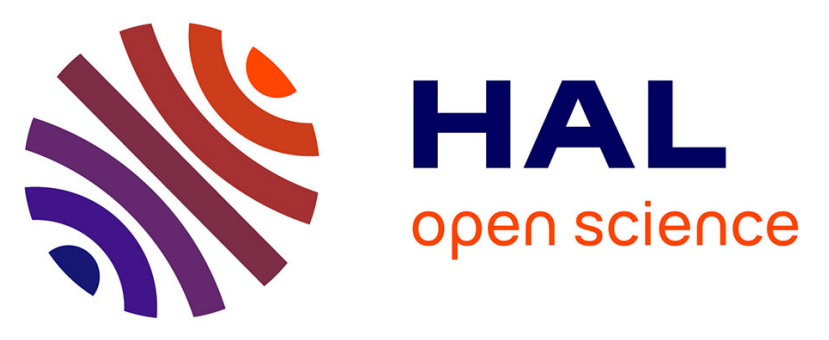

\title{
Regulation of hepatokine gene expression in response to fasting and feeding: Influence of PPARa and insulin-dependent signaling in hepatocytes
}

Sarra Smati, Marion Régnier, Tiffany Fougeray, Arnaud Polizzi, Anne

Fougerat, Frédéric Lasserre, Céline Lukowicz, Blandine Tramunt, Maeva

Guillaume, Anne-Francoise Burnol, et al.

\section{To cite this version:}

Sarra Smati, Marion Régnier, Tiffany Fougeray, Arnaud Polizzi, Anne Fougerat, et al.. Regulation of hepatokine gene expression in response to fasting and feeding: Influence of PPARa and insulin-dependent signaling in hepatocytes. Diabetes \& Metabolism, 2020, 46 (2), pp.129-136. 10.1016/j.diabet.2019.05.005 . hal-02402566

\section{HAL Id: hal-02402566 https://hal.science/hal-02402566}

Submitted on 10 Dec 2019

HAL is a multi-disciplinary open access archive for the deposit and dissemination of scientific research documents, whether they are published or not. The documents may come from teaching and research institutions in France or abroad, or from public or private research centers.
L'archive ouverte pluridisciplinaire HAL, est destinée au dépôt et à la diffusion de documents scientifiques de niveau recherche, publiés ou non, émanant des établissements d'enseignement et de recherche français ou étrangers, des laboratoires publics ou privés. 


\section{Regulation of hepatokine gene expression in response to fasting and feeding: Influence of PPAR $\alpha$ and insulin-dependent signaling in hepatocytes}

Sarra Smati ${ }^{\mathrm{a}, \mathrm{b}}$, Marion Régnier ${ }^{\mathrm{a}}$, Tiffany Fougeray ${ }^{\mathrm{a}}$, Arnaud Polizzi ${ }^{\mathrm{a}}$, Anne Fougerat ${ }^{\mathrm{a}}$, Frédéric Lasserre ${ }^{\mathrm{a}}$, Céline Lukowicz ${ }^{\mathrm{a}}$, Blandine Tramunt ${ }^{\mathrm{b}}$, Maeva Guillaume ${ }^{\mathrm{b}}$, AnneFrançoise Burnol ${ }^{\mathrm{c}}$, Catherine Postic ${ }^{\mathrm{c}}$, Walter Wahlia,d,e, Alexandra Montagner ${ }^{\mathrm{b}}$, Pierre Gourdy b,f,\#, Hervé Guillou, ${ }^{\mathrm{a}, \#}$

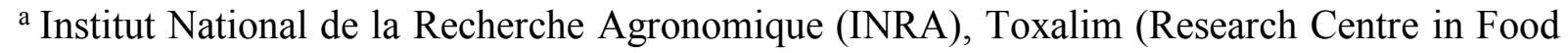
Toxicology), UMR 1331, Toulouse, France

${ }^{\mathrm{b}}$ Institute of Metabolic and Cardiovascular Diseases (I2MC), UMR 1048, Institut National de la Santé et de la Recherche Médicale (INSERM) and Université de Toulouse, Toulouse, France

${ }^{\mathrm{c}}$ Institut National de la Santé et de la Recherche Médicale (INSERM U1016), Institut Cochin, Paris 75014, France; CNRS UMR 8104, Paris 75014, France; University of Paris Descartes, Sorbonne Paris Cité, Paris 75005, France

d Lee Kong Chian School of Medicine, Nanyang Technological University Singapore, Clinical Sciences Building, 11 Mandalay Road, Singapore 308232

e Center for Integrative Genomics, Université de Lausanne, Le Génopode, Lausanne, Switzerland

${ }^{\mathrm{f}}$ Diabetology Department, CHU de Toulouse, Toulouse, France

\# Correspondence to: herve.guillou@inra.fr and/or pierre.gourdy@inserm.fr

\section{ABSTRACT}

Aim. - In hepatocyte, PPAR $\alpha$ and insulin receptor (IR) are critical for the transcriptional responses to fasting and feeding, respectively. Here we analyzed the effects of the nutritional status (fasting vs feeding) on the expression of a large panel of hepatokines in hepatocytespecific PPAR $\alpha\left(\right.$ Ppar $\left.^{\text {hep-l- }}\right)$ and IR $\left(I R^{\text {hep-/-}}\right)$ null mice.

Methods. - Ppar $\alpha^{h e p-/-}$, and $I R^{\text {hep-/- }}$ mice and their wild-type littermate were subjected to fasting or feeding metabolic challenges, and then analyzed for hepatokine gene expression. Experiments were conducted in mice of both sexes. 
Results. - Our data confirmed that PPAR $\alpha$ is critical for regulating fasting-induced $F g f 21$ and Angptl4 expression. In mice lacking PPAR $\alpha$, fasting led to an increased Igfbpl and Gdf15 expression. In the absence of hepatic IR, feeding induced overexpression of Igfbpl, follistatin $(F s t)$, and adropin (Enho). We also observed reduced activin E (Inhbe) expression in $I R^{h e p-/-}$ mice. Sex only had a modest influence on hepatokine gene expression in the liver.

Conclusion. - The present results highlight the potential roles of hepatokines as a class of hormones that substantially influence nutritional regulation in both females and males.

Keywords: Hepatokines, PPAR $\alpha$, Insulin receptor, Nutritional regulations 


\section{Introduction}

The liver exhibits highly flexible metabolic activity, which requires major transcriptional regulation. During fasting, hepatocytes show elevated expression of thousands of genes, including those involved in fatty acid catabolism and ketogenesis. This catabolic adaptation to starvation strongly relies on transcriptional control by the nuclear receptor peroxisome proliferator-activated receptor $\alpha(\operatorname{PPAR} \alpha)$ [1]. In response to feeding, insulin stimulates hepatic synthesis of glycogen and fatty acids. This anabolic response to insulin also includes extensive changes in the expression of various genes, including transcription factors such as forkhead box protein $\mathrm{O} 1$ (FoxO1) and sterol regulatory element binding protein 1c (Srebp1c) [2].

In addition to altering the expression of rate-limiting metabolic enzymes, fasting and feeding also influence the synthesis and secretion of numerous proteins, including hepatokines. Hepatokines are proteins secreted from the hepatocytes, which act as hormones and are involved in autocrine, paracrine, and endocrine signaling. The first discovered and most well-known hepatokine is fibroblast growth factor 21 (Fgf21), which is strongly induced in response to fasting through a mechanism involving transcriptional control via PPAR $\alpha$ [3]. Since the discovery of Fgf21, several other hepatokines have been identified and shown to be involved in many endocrine regulations. Some of these hepatokines are related to the pathogeny of type 2 diabetes and other metabolic disorders, such as non-alcoholic liver fatty diseases [4]. Such hepatokines include not only Fgf21 [5] but also adropin [6], Angpt14 [7], fetuin-A [8], fetuin-B [9], hepassocin [10], Lect2 [11], follistatin [12], Gdf15 [13], Rbp4 [14] and selenoprotein P [15]. The transcriptional control of Fgf21 expression in hepatocytes has been extensively studied [3] and shown to be highly dependent on nutritional regulations $[16,17]$.

In the present study, we analyzed the respective effects of fasting and feeding on the hepatic expression of a large panel of hepatokines identified to date. Since PPAR $\alpha$ and the insulin receptor (IR) are critical for the hepatic transcriptional responses to fasting and feeding, respectively, we analyzed hepatokine gene expression in liver tissue from mice with hepatocyte-specific deletion of either PPAR $\alpha\left(\right.$ Ppar $\left.^{\text {hep-/--}}\right)$ or IR $\left(I R^{h e p-/-}\right)$. Given the wellestablished sexual dimorphism in liver and metabolic homeostasis [18], we performed these analysis in both sexes. Our data thus provide an overview of hepatokine regulation via PPAR $\alpha$ and IR signaling, according to the nutritional status. 


\section{Materials and methods}

Mice

In vivo studies were conducted following the EU guidelines for the use and care of laboratory animals, and protocols were approved by an independent local ethics committee. Ppara $^{\text {hep-/- }}$ animals were created at INRA's rodent facility (Toulouse, France) as previously described by Montagner et al. [19]. To generate the hepatocyte-specific IR knockout mouse line [20], mice carrying the LoxP sites flanking the fourth exon of the $I R$ gene $\left(I R^{l o x} / l o x\right.$ stock number: 006955; Jackson Laboratory, USA) were intercrossed with C57BL/6J mice, which specifically express the Cre recombinase in the liver under the transthyretin promoter (TTR$\mathrm{Cre}^{\mathrm{Tam}}$ mice), as previously described by Nemazanyy et al. [20]. Mice were fed a standard rodent diet (Safe 04 U8220G10R). Mice were housed with controlled temperature $\left(21-23^{\circ} \mathrm{C}\right)$ and light (12-h light/12-h dark). The lights were turned on at Zeitgeber time (ZT) 0, and turned off at ZT12. Twelve-week-old male and female mice were sacrificed at ZT16 either fed ad libitum or fasted for $20 \mathrm{~h}$ with free access to water. Female estrus cycle was synchronized using male urine, so that all females were in proestrus or estrus at the time of sacrifice.

\section{Immunoblotting}

Frozen liver, white and brown adipose tissue samples were homogenized in lysis buffer (50 mM Tris-HCl [pH 7.4], $150 \mathrm{mM} \mathrm{NaCl}, 1 \%$ NP-40, 0.25\% Sodium Deoxycholate, $0.1 \%$ SDS, $2 \mathrm{mM}$ EDTA and $1 \mathrm{mM}$ PMSF) supplemented with $2 \mu \mathrm{g} / \mathrm{mL}$ apropotinin, 5 $\mu \mathrm{g} / \mathrm{mL}$ leupeptin and $1 \mathrm{mM}$ sodium orthovanadate for $30 \mathrm{~min}$ at $4^{\circ} \mathrm{C}$. Samples were then centrifuged at $13000 \mathrm{rpm}$ for 30 minutes at $4^{\circ} \mathrm{C}$. Supernatants were collected and protein concentration in each lysate was measured using BC Assay Protein Quantitation Kit (Interchim). Proteins $(50 \mu \mathrm{g})$ were separated by SDS-PAGE and transferred onto nitrocellulose membranes. Membranes were incubated with primary antibodies against insulin receptor $\beta$ (sc-57342, Santa Cruz Biotechnology) and $\beta$-actin (4970, Cell Signaling) overnight at $4{ }^{\circ} \mathrm{C}$ and then with horseradish peroxidase-conjugated secondary antibodies (anti-mouse and anti-rabbit, respectively) for $1 \mathrm{~h}$ at room temperature. Immunoreactive proteins were detected with Clarity Western ECL (Bio-Rad) according to the manufacturer's instructions and signals were acquired using Chemidoc touch imaging system (Bio-Rad).

\section{Blood and tissue samples}


Prior to sacrifice, the submandibular vein was lanced, and blood was collected into EDTA-coated tubes (BD Microtainer, K2E tubes). Plasma was prepared by centrifugation $\left(1500 \times g, 10 \mathrm{~min}, 4^{\circ} \mathrm{C}\right)$ and stored at $-80^{\circ} \mathrm{C}$. Mice were killed by cervical dislocation, and organs were removed, weighed, dissected (when necessary), and prepared for histological analysis or snap-frozen in liquid nitrogen and stored at $-80^{\circ} \mathrm{C}$.

\section{Gene expression analysis}

Total cellular RNA was extracted using Tri reagent (Molecular Research Center). Total RNA samples $(2 \mu \mathrm{g})$ were reverse-transcribed using the High Capacity cDNA Reverse Transcription Kit (Applied Biosystems) for real-time quantitative polymerase chain reaction (qPCR) analyses. Supplementary Table 1 presents the primers used for SYBR Green assays. Amplifications were performed using a Stratagene Mx3005P (Agilent Technology). The qPCR data were normalized to the level of TATA-box binding protein (Tbp) transcripts, and analyzed using LinRegPCR.22.

\section{Biochemical analysis}

Plasma samples were assayed for free fatty acid, triglyceride, total cholesterol, and low-density lipoprotein (LDL) cholesterol levels using a COBAS-MIRA + biochemical analyzer (Anexplo facility).

\section{Measurement of blood glucose and ketone bodies}

Blood glucose was measured using an Accu-Chek Go glucometer (Roche Diagnostics). $\beta$-hydroxybutyrate content was measured using Optium $\beta$-ketone test strips that carried Optium Xceed sensors (Abbott Diabetes Care).

\section{Statistical analysis}

Data were analyzed using GraphPad Prism 7. Differential effects were assessed on natural logarithm (ln)-transformed data by performing analyses of variance, followed by Student's $t$-tests with a pooled variance estimate. $P$-values from $t$-tests were adjusted with Sidak's correction. A $P$-value of $<0.05$ was considered significant.

\section{Results}

Male and female Ppar $\alpha^{\text {hep-/- }}$ mice and their Ppar $\alpha^{\text {hep }+/+}$ littermates were sacrificed after being fasted for 20 hours or fed ad libitum. First, we confirmed the deletion of Ppar $\alpha$ 
and its reduced activity in the liver of $\operatorname{Ppar}^{\text {hep-/- }}$ mice by measuring Ppar $\alpha$ mRNA and the expression of Cyp4a10, one of the most specific PPAR $\alpha$ target genes (Fig. 1A). Body and liver weights, presented in Fig. 1B were not dependent on genotype. As expected, fasted Ppar $\alpha^{h e p-/-}$ mice of both sexes exhibited significantly reduced ketone body levels compared to fasted Ppar $\alpha^{\text {hep+/+ }}$ mice (Fig. 1C). Except for LDL-cholesterol in males, plasma lipids were not significantly different between genotypes (Fig. 1C). We then confirmed that $F g f 21$ expression was induced by fasting, through a mechanism dependent on hepatocyte PPAR $\alpha$ (Fig. 2A and B). Similar results were observed for the hepatokines Igfbp2, Angptl4 and Inhbe (Fig. 2A, 2B, S1). Interestingly, the expression of $G d f 15$ and $I g f b p l$ was upregulated in liver of fasted Ppard ${ }^{h e p-/-}$ mice (Fig. 2B), irrespective of sex. We identified Serpinbla as upregulated in the liver of fed Ppar $\alpha^{h e p-/-}$ mice, most significantly in females (Fig. S1). Fig. S1 presents the detailed relative expression levels of other hepatokines.

Male and female $I R^{\text {hep-/- }}$ mice and their $I R^{\text {hept/+ }}$ littermates were also sacrificed after being fasted for 20 hours or fed ad libitum. We first confirmed the specific deletion of $I R$ in hepatocytes by assessing its reduced expression in the liver but not in white and brown adipose tissues (Fig. 3A). We also evaluated the expression of Fasn, a well-known insulin sensitive gene, in the liver of $I R^{h e p+/+}$ and $I R^{h e p-/-}$ mice and observed a profile consistent with the deletion of IR (Fig. 3B). Body and liver weights are presented in Fig. 3C. Fed male $I R^{h e p-/-}$ mice exhibited significant hyperglycemia compared to $I R^{h e p+/+}$ mice (Fig. 3D). In contrast, no difference in fasting and/or fed blood glucose was observed in female mice from both genotypes. Total plasma cholesterol concentration was reduced in both male and female $I R^{\text {hep-/- }}$ mice as compared to their respective $I R^{\text {hep }+/+}$ littermates (Fig. 3D). Moreover, we found that the expression of Ppar $\alpha$ itself and one of its specific target gene Cyp4a10 was not altered upon deletion of $I R$ in the liver (Fig. 3E). We also analyzed hepatokine gene expression in response to fasting in both sexes (Fig. 4A). The fasting-mediated induction of $F g f 21$ was not dependent on hepatic IR. Upon fasting, Igfbpl was upregulated in $I R^{\text {hep-l- }}$ mice from both sexes (Fig. 4B), while $I g f b p 2$ expression was only upregulated in $I R^{\text {hep+/+ }}$ mice (Fig. 4A). Under fed condition, hepatocyte IR deletion led to an increased expression of Igfbp1, Igfbp2, Enho (adropin), Fst (follistatin), Fetuin-a, Fetuin-b, Fgl (hepassocin), Postn (periostin), Rbp4, Seppl (selenoprotein) and Serpinbla and to a reduced expression of Inhbe (activin E), Angptl8, Lect2 and Tsku (tsukushi) (Fig. 4B, S2). Fig. S2 presents the detailed relative expression levels of other hepatokines. 


\section{Discussion}

During fasting and feeding, the liver adjusts its metabolism via extensive regulation of gene expression. Fasting and feeding also strongly impact on protein expression and secretion by hepatocytes. The affected proteins include hepatokines, which act as hepatic hormones with systemic effects on metabolism, growth, behavior, and fertility [4]. Here we investigated the potential regulation of hepatokines by two receptors that play critical roles in metabolic homeostasis, namely PPAR $\alpha$ and IR.

PPAR $\alpha$ is a nuclear receptor that orchestrates a broad range of fasting-induced changes in hepatic gene expression, notably, playing a critical role in regulating the expression of the hepatokines Angpt14 [7] and Fgf21 [3,19]. Our present data confirm that fasting induces Fgf21 and Angptl4 expression in a PPAR $\alpha$-dependent manner. Importantly, we found that fasting also induced Gdf15 and Igfbpl expression in Ppar $\alpha^{\text {hep-/- }}$ mice. Previous studies reported the fasting-mediated induction of $F g f 21$, Gdf15, and Igfbpl expression in mice with defective fatty acid oxidation in hepatocytes resulting from carnitine palmitoyltransferase 2 (CPT2) deficiency [21]. Our current data support these observations and reveal that, unlike $F g f 21$, both $G d f 15$ and $I g f b p l$ can be induced in the absence of hepatic PPAR $\alpha$. Igfbpl [22,23] and Gdf15 [24] are known to be induced by amino acid deprivation. Therefore, their PPAR $\alpha$-independent increase in response to fasting may occur as a consequence of amino acid restriction. Moreover, this response was enhanced when PPAR $\alpha$ was inactive. In the fasting state, this suggests the existence of at least one PPAR $\alpha-$ independent mechanism in hepatocytes, such that the overexpression of Gdf15 and Igfbpl triggers a systemic hormetic response in the setting of defective liver fatty acid oxidation. This response might be involved in the critical dialogue between the liver and the white adipose tissue during fasting [19]. Our data also first reveal that the absence of hepatocyte PPAR $\alpha$ up-regulates serpinB1a which was identified as an insulin sensitive hepatokine regulating pancreatic $\beta$-cell proliferation [25], which may contribute to the effect of PPAR $\alpha$ on glucose homeostasis [26].

While fasting-induced catabolic pathways are driven by PPAR $\alpha$ in hepatocytes, feeding-induced anabolic pathways are triggered by insulin signals through IR, which activates the PI3K-AKT pathway, thereby inhibiting gluconeogenesis while promoting glycogen and lipid synthesis. Here we investigated whether feeding regulates hepatokine expression in hepatocytes through IR-dependent signaling. Igfbp1 is a well-known target of FoxO1 [27], a transcription factor that translocates from the nucleus to the cytoplasm upon 
insulin-induced activation of PI3K-AKT signaling. As expected, we found increased Igfbpl expression in the absence of IR. Our data also confirm that hepatocyte IR deficiency increases Serpinbla expression [25]. Similarly, the lack of IR in hepatocytes promoted the expression of follistatin $(F s t)$, another FoxO1-regulated hepatokine, which was recently identified as a regulator of glucose homeostasis through its effect on adipose tissue [12]. We also provide evidence that hepatic IR influenced the expression of two other hepatokines. Adropin (Enho), a hepatokine linked to macronutrient intake [6], was upregulated in fed $I R^{\text {hep-/- }}$ mice, while activin E (Inhbe) was downregulated in liver of these mice. Activin E was recently identified as an important modulator of adipocyte browning and insulin sensitivity [28]. Our observations suggest that increased adropin (Enho) and reduced activin E (Inhbe) expression in the context of defective hepatic IR signaling may represent, together with elevated follistatin $(F s t)$, an additional mechanism through which hepatic insulin resistance promotes peripheral defects in glucose homeostasis. In this study performed during the night, when mice are active and feeding, we observed that IR deficiency in hepatocytes promotes hyperglycemia in males but not in females. This might reflect sexually dimorphic glucose homeostasis [29] but further investigations are required to define the mechanisms underlying this difference. However, in the fed state, hepatokine expression profiles in mice lacking hepatocyte IR are not sexually dimorphic, with the exception of Igfbp1. Low levels of IGFBP1 have been associated with incidence of type 2 diabetes [30], suggesting that, in our experimental setting, Igfbpl may account, at least in part, for the difference in glycemia in fed $I R^{\text {hep-/- }}$ mice between sexes. Finally, fed mice lacking IR in hepatocytes did not show any significant changes in the expression of $\mathrm{Fgf2} 1$ and Angptl4, suggesting that fasting-induced expression of these hepatokines dependent on PPAR $\alpha[7,16]$ is not under direct control by insulin signaling in hepatocytes.

Altogether our data support and underline the potential roles of hepatokines as a class of hormones that strongly influence nutritional regulations in both males and females. Our findings in mouse models lacking hepatocytic PPAR $\alpha$ or IR signaling elucidate changes in hepatokine expression under conditions of defective hepatic homeostasis. Hepatokines are potential biomarkers for NAFLD and insulin resistance [4]. Our work suggests that in the fasted state, reduced $F g f 21$ combined with $G d f 15$ overexpression may reflect impaired hepatocyte PPAR $\alpha$ activity, which predisposes to steatosis. While in the fed state, follistatin [12] but also adropin and activin E levels may be associated with hepatic insulin resistance. Further research is needed to test whether hepatic expression profile correlates with the 
circulating level of these hormones and to investigate the clinical relevance of these observations.

\section{Legends}

Fig. 1. Male and female wild-type (PPAR $\left.\alpha^{\text {hep+/+}}\right)$ and hepatocyte-specific knockout (PPAR $\alpha^{\text {hep---}}{ }^{-}$mice were fed ad libitum or fasted for $20 \mathrm{~h}$ and then sacrificed. In female mice, the estrus cycle was synchronized in proestrus or estrus at the time of sacrifice. A. Relative gene expression of Ppar $\alpha$ and of a specific PPAR $\alpha$ target gene Cyp4a10 from liver samples of PPAR $\alpha^{\text {hept/+ }}$ and PPAR $\alpha^{\text {hep-l- }}$ mice. B. Body weight and relative liver weight measured at the time of sacrifice. C. Quantification of plasma glucose (glycemia), ketone bodies (ketonemia), free fatty acids (FFA), triglycerides (TG), total cholesterol, and low-density lipoprotein $(\mathrm{LDL})$ cholesterol. Data shown are mean \pm SEM. \# significant nutritional status effect, * genotype effect, \#<0.05, \#\#<0.01, \#\#\#<0.001.

Fig. 2. Male and female wild-type (PPAR $\left.\alpha^{\text {hep }+/+}\right)$ and hepatocyte-specific knockout (PPAR $\alpha^{\text {hep---}}$ ) mice were fed ad libitum or fasted for $20 \mathrm{~h}$, and then sacrificed ( $\mathrm{n}=6 /$ group). In females, the estrus cycle was synchronized in proestrus or estrus at the time of sacrifice. $\mathbf{A}$. Heat map representing qRT-PCR data (Z-scores) for hepatokine genes from liver samples, according to genotype (PPAR $\alpha^{\text {hep-/- }}$ or PPAR $\alpha^{\text {hep }+/+}$ ) and nutritional condition in males and females. B. Mean \pm SEM of the relative gene expressions of Fgf21, Angptl4, Gdf15, and Igfbpl measured by qRT-PCR in PPAR $\alpha^{\text {hep-/- }}$ or PPAR $\alpha^{\text {hep+// }}$ mice. \# significant nutritional status effect, $*$ genotype effect, $\#<0.05, \# \#<0.01$, \#\#\#<0.001.

Fig. 3. Male and female wild-type $\left(\mathrm{IR}^{\text {hep }}{ }^{+/+}\right)$and hepatocyte-specific knockout $\left(\mathrm{IR}^{\text {hep-/- }}\right.$ ) mice were fed ad libitum or fasted for $24 \mathrm{~h}$ and then sacrificed. In female mice, the estrus cycle was synchronized in proestrus or estrus at the time of sacrifice. A. IR levels was determined by Western blot analysis from liver, white and brown adipose tissue (WAT and BAT) samples. B. Relative gene expression of Fasn from liver samples of $\mathrm{IR}^{\text {hep+//+ }}$ and $\mathrm{IR}^{\text {hep-/- }}$ mice. C. Body weight and relative liver weight measured at time of sacrifice. D. Quantification of plasma glucose (glycemia), ketone bodies (ketonemia), free fatty acids (FFA), triglycerides (TG), total cholesterol, and low-density lipoprotein (LDL) cholesterol. E. Relative gene expression of Ppar $\alpha$ and of a specific PPAR $\alpha$ target gene Cyp4a10 from liver samples of $\mathrm{IR}^{\text {hep }}{ }^{+/+}$and 
$\mathrm{IR}^{\text {hep-l- }}$ mice. Data shown are mean \pm SEM. \# significant nutritional status effect, * genotype effect, \#<0.05, \# $<0.01$, \#\#\#<0.001.

Fig. 4. Male and female wild-type $\left(\mathrm{IR}^{\text {hep }+/+}\right)$ and hepatocyte-specific knockout (IR $\left.{ }^{\text {hep }-/-}\right)$ mice were fed ad libitum or fasted for $20 \mathrm{~h}$, and then sacrificed (n=6/group). In females, the estrus cycle was synchronized in proestrus or estrus at the time of sacrifice. A. Heat map representing qRT-PCR data (Z-scores) for hepatokine genes from liver samples, according to genotype (IR ${ }^{\text {hep-/- }}$ or $\mathrm{IR}^{\text {hep+/++}}$ ) and nutritional condition in males and females. B. Mean $\pm \mathrm{SEM}$ of the relative gene expressions of Igfbpl, Fst, Enho, and Inhbe measured by qRT-PCR in $\mathrm{IR}^{\text {hep-/- }}$ or IR $\mathrm{IR}^{\text {hep+/ }}$ mice. \# significant nutritional status effect, * genotype effect, \#<0.05, \#\# $<0.01, \ldots \#<0.001$.

Supplementary data Fig. S1. Relative gene expression of Angptl6, Angptl8, Ctsd, Enho, Fetuin a, Fetuin b, Fgl1, Fst, Igf1, Igfbp2, Igfbp3, Inhbe, Lect2, Postn, Rbp4, Sepp1, Serpinbla and Tsku measured by qRT-PCR in PPAR $\alpha^{\text {hep }}{ }^{+/+}$and PPAR $\alpha^{\text {hep-/- }}$ mice. Data shown are mean \pm SEM. \# significant nutritional status effect, * genotype effect, $\#<0.05$, \#\# $<0.01$, \#\#\# <0.001.

Supplementary data Fig. S2. Relative gene expression of Angptl4, Angptl6, Angptl8, Ctsd, Fetuin a, Fetuin b, Fgf21, Fgl1, Gdf15, Igf1, Igfbp2, Igfbp3, Lect2, Postn, Rbp4, Sepp1, Serpinbla and Tsku measured by qRT-PCR in IR $\mathrm{IRp}^{\text {h/+ }}$ and IR $\mathrm{IRp}^{\text {he-/ }}$ mice. Data shown are mean \pm SEM. \# significant nutritional status effect, $*$ genotype effect, $\#<0.05$, \#\# $<0.01$, \#\#\# $<0.001$.

\section{Acknowledgments}

We thank all members of the EZOP staff for their help from the beginning of this project. We thank Léa Morra-Charrot and Laurent Monbrun for their excellent work on plasma biochemistry. We thank the staff from the Genotoul: Anexplo, GeT-TRiX, and Metatoul-Lipidomic facilities. We also thank Pr. Daniel Metzger, Pr. Pierre Chambon (IGBMC, Illkirch, France), and the staff of the Mouse Clinical Institute (Illkirch, France) for 
their critical support in this project. Finally, we thank Pr. Didier Trono (EPFL, Lausanne, Switzerland) for providing the Albumin-Cre mice.

\section{Funding}

S.S. is supported by a PhD grant from INSERM. P.G and A.M. are supported by grants from the "Société Francophone du Diabète" and the "Société Française de Nutrition". W.W. is supported by the Lee Kong Chian School of Medicine, Nanyang Technological University, Singapore, start-up Grant. This work was funded by ANR "Hepatokind" (to C.P., and H.G.). W.W., A.M., P.G., H.G. were supported by grants from the Région Occitanie. 


\section{References}

[1] Kersten S, Seydoux J, Peters JM, Gonzalez FJ, Desvergne B, Wahli W. Peroxisome proliferator-activated receptor alpha mediates the adaptive response to fasting. J Clin Invest 1999;103:1489-98. doi:10.1172/JCI6223.

[2] Titchenell PM, Lazar MA, Birnbaum MJ. Unraveling the Regulation of Hepatic Metabolism by Insulin. Trends Endocrinol Metab 2017;28:497-505. doi:10.1016/j.tem.2017.03.003.

[3] Badman MK, Pissios P, Kennedy AR, Koukos G, Flier JS, Maratos-Flier E. Hepatic Fibroblast Growth Factor 21 Is Regulated by PPAR $\alpha$ and Is a Key Mediator of Hepatic Lipid Metabolism in Ketotic States. Cell Metab 2007;5:426-37. doi:10.1016/J.CMET.2007.05.002.

[4] Meex RCR, Watt MJ. Hepatokines: linking nonalcoholic fatty liver disease and insulin resistance. Nat Rev Endocrinol 2017;13:509-520. doi:10.1038/nrendo.2017.56.

[5] Markan KR, Naber MC, Ameka MK, Anderegg MD, Mangelsdorf DJ, Kliewer SA, et al. Circulating FGF21 is liver derived and enhances glucose uptake during refeeding and overfeeding. Diabetes 2014;63:4057-63. doi:10.2337/db14-0595.

[6] Kumar KG, Trevaskis JL, Lam DD, Sutton GM, Koza RA, Chouljenko VN, et al. Identification of Adropin as a Secreted Factor Linking Dietary Macronutrient Intake with Energy Homeostasis and Lipid Metabolism. Cell Metab 2008;8:468-81. doi:10.1016/j.cmet.2008.10.011.

[7] Kersten S, Mandard S, Tan NS, Escher P, Metzger D, Chambon P, et al. Characterization of the fasting-induced adipose factor FIAF, a novel peroxisome proliferator-activated receptor target gene. J Biol Chem 2000;275:28488-93. doi:10.1074/jbc.M004029200.

[8] Mathews ST, Singh GP, Ranalletta M, Cintron VJ, Qiang X, Goustin AS, et al. Improved insulin sensitivity and resistance to weight gain in mice null for the Ahsg gene. Diabetes 2002;51:2450-8.

[9] Meex RC, Hoy AJ, Morris A, Brown RD, Lo JCY, Burke M, et al. Fetuin B Is a Secreted Hepatocyte Factor Linking Steatosis to Impaired Glucose Metabolism. Cell Metab 2015;22:1078-89. doi:10.1016/j.cmet.2015.09.023.

[10] Wu HT, Lu FH, Ou HY, Su YC, Hung HC, Wu JS, et al. The role of Hepassocin in the 
development of non-alcoholic fatty liver disease. J Hepatol 2013;59:1065-72. doi:10.1016/j.jhep.2013.06.004.

[11] Lan F, Misu H, Chikamoto K, Takayama H, Kikuchi A, Mohri K, et al. LECT2 functions as a hepatokine that links obesity to skeletal muscle insulin resistance. Diabetes 2014;63:1649-64. doi:10.2337/db13-0728.

[12] Tao R, Wang C, Stöhr O, Qiu W, Hu Y, Miao J, et al. Inactivating hepatic follistatin alleviates hyperglycemia. Nat Med 2018:1. doi:10.1038/s41591-018-0048-0.

[13] Tsai VWW, Macia L, Feinle-Bisset C, Manandhar R, Astrup A, Raben A, et al. Serum levels of human MIC-1/GDF15 vary in a diurnal pattern, do not display a profile suggestive of a satiety factor and are related to BMI. PLoS One 2015;10:e133362. doi:10.1371/journal.pone.0133362.

[14] Yang Q, Graham TE, Mody N, Preitner F, Peroni OD, Zabolotny JM, et al. Serum retinol binding protein 4 contributes to insulin resistance in obesity and type 2 diabetes. Nature 2005;436:356-62. doi:10.1038/nature03711.

[15] Misu H, Takayama H, Saito Y, Mita Y, Kikuchi A, Ishii K, et al. Deficiency of the hepatokine selenoprotein $\mathrm{P}$ increases responsiveness to exercise in mice through upregulation of reactive oxygen species and AMP-activated protein kinase in muscle. Nat Med 2017;23:508-16. doi:10.1038/nm.4295.

[16] Inagaki T, Dutchak P, Zhao G, Ding X, Gautron L, Parameswara V, et al. Endocrine Regulation of the Fasting Response by PPAR $\alpha$-Mediated Induction of Fibroblast Growth Factor 21. Cell Metab 2007;5:415-25. doi:10.1016/j.cmet.2007.05.003.

[17] Von Holstein-Rathlou S, Bondurant LD, Peltekian L, Naber MC, Yin TC, Claflin KE, et al. FGF21 mediates endocrine control of simple sugar intake and sweet taste preference by the liver. Cell Metab 2016;23:335-43. doi:10.1016/j.cmet.2015.12.003.

[18] Kautzky-Willer A, Harreiter J, Pacini G. Sex and Gender Differences in Risk, Pathophysiology and Complications of Type 2 Diabetes Mellitus. Endocr Rev 2016;37:278-316. doi:10.1210/er.2015-1137.

[19] Montagner A, Polizzi A, Fouché E, Ducheix S, Lippi Y, Lasserre F, et al. Liver PPAR $\alpha$ is crucial for whole-body fatty acid homeostasis and is protective against NAFLD. Gut 2016;65:1202-14. doi:10.1136/gutjnl-2015-310798.

[20] Nemazanyy I, Montagnac G, Russell RC, Morzyglod L, Burnol A-F, Guan K-L, et al. 
Class III PI3K regulates organismal glucose homeostasis by providing negative feedback on hepatic insulin signalling. Nat Commun 2015;6:8283. doi:10.1038/ncomms9283.

[21] Lee J, Choi J, Scafidi S, Wolfgang MJ. Hepatic Fatty Acid Oxidation Restrains Systemic Catabolism during Starvation. Cell Rep 2016;16:201-12. doi:10.1016/j.celrep.2016.05.062.

[22] Averous J, Maurin A-C, Bruhat A, Jousse C, Arliguie C, Fafournoux P. Induction of IGFBP-1 expression by amino acid deprivation of HepG2 human hepatoma cells involves both a transcriptional activation and an mRNA stabilization due to its 3'UTR. FEBS Lett 2005;579:2609-14. doi:10.1016/j.febslet.2005.03.077.

[23] Jousse C, Bruhat A, Ferrara M, Fafournoux P. Physiological concentration of amino acids regulates insulin-like-growth-factor-binding protein 1 expression. Biochem $\mathrm{J}$ 1998;334 ( Pt 1):147-53. doi:10.1042/bj3340147.

[24] Patel S, Alvarez-Guaita A, Melvin A, Rimmington D, Dattilo A, Miedzybrodzka EL, et al. GDF15 Provides an Endocrine Signal of Nutritional Stress in Mice and Humans. Cell Metab 2019;29:707-718.e8. doi:10.1016/j.cmet.2018.12.016.

[25] El Ouaamari A, Dirice E, Gedeon N, Hu J, Zhou J-Y, Shirakawa J, et al. SerpinB1 Promotes Pancreatic $\beta$ Cell Proliferation. Cell Metab 2016;23:194-205. doi:10.1016/j.cmet.2015.12.001.

[26] Guerre-Millo M, Rouault C, Poulain P, André J, Poitout V, Peters JM, et al. PPARalpha-null mice are protected from high-fat diet-induced insulin resistance. Diabetes 2001;50:2809-14.

[27] Guo S, Rena G, Cichy S, He X, Cohen P, Unterman T. Phosphorylation of serine 256 by protein kinase B disrupts transactivation by FKHR and mediates effects of insulin on insulin-like growth factor-binding protein-1 promoter activity through a conserved insulin response sequence. J Biol Chem 1999;274:17184-92.

[28] Hashimoto O, Funaba M, Sekiyama K, Doi S, Shindo D, Satoh R, et al. Activin E Controls Energy Homeostasis in Both Brown and White Adipose Tissues as a Hepatokine. Cell Rep 2018;25:1193-203. doi:10.1016/j.celrep.2018.10.008.

[29] Yan H, Yang W, Zhou F, Li X, Pan Q, Shen Z, et al. Estrogen Improves Insulin Sensitivity and Suppresses Gluconeogenesis via the Transcription Factor Foxo1. 
Diabetes 2019;68:291-304. doi:10.2337/DB18-0638.

[30] Lewitt MS, Hilding A, Östenson C-G, Efendic S, Brismar K, Hall K. Insulin-like growth factor-binding protein-1 in the prediction and development of type 2 diabetes in middle-aged Swedish men. Diabetologia 2008;51:1135-45. doi:10.1007/s00125-0081016-x.

[31] Oike Y, Akao M, Yasunaga K, Yamauchi T, Morisada T, Ito Y, et al. Angiopoietinrelated growth factor antagonizes obesity and insulin resistance. Nat Med 2005;11:400-8. doi:10.1038/nm1214.

[32] Zhang R. Lipasin, a novel nutritionally-regulated liver-enriched factor that regulates serum triglyceride levels. Biochem Biophys Res Commun 2012;424:786-92. doi:10.1016/j.bbrc.2012.07.038.

[33] Houben T, Oligschlaeger Y, Hendrikx T, Bitorina A V, Walenbergh SMA, Van Gorp PJ, et al. Cathepsin D regulates lipid metabolism in murine steatohepatitis. Sci Rep 2017;7:3494. doi:10.1038/s41598-017-03796-5.

[34] Markan KR, Naber MC, Ameka MK, Anderegg MD, Mangelsdorf DJ, Kliewer SA, et al. Circulating FGF21 is liver derived and enhances glucose uptake during refeeding and overfeeding. Diabetes 2014;63:4057-63. doi:10.2337/db14-0595.

[35] Tsai VWW, Macia L, Johnen H, Kuffner T, Manadhar R, Jørgensen SB, et al. TGF-b Superfamily Cytokine MIC-1/GDF15 Is a Physiological Appetite and Body Weight Regulator. PLoS One 2013;8. doi:10.1371/journal.pone.0055174.

[36] Wheatcroft SB, Kearney MT. IGF-dependent and IGF-independent actions of IGFbinding protein-1 and -2: implications for metabolic homeostasis. Trends Endocrinol Metab 2009;20:153-62. doi:10.1016/j.tem.2009.01.002.

[37] Lu Y, Liu X, Jiao Y, Xiong X, Wang E, Wang X, et al. Periostin promotes liver steatosis and hypertriglyceridemia through downregulation of PPAR $\alpha$. J Clin Invest 2014;124:3501-13. doi:10.1172/JCI74438.

[38] Yang Q, Graham TE, Mody N, Preitner F, Peroni OD, Zabolotny JM, et al. Serum retinol binding protein 4 contributes to insulin resistance in obesity and type 2 diabetes. Nature 2005;436:356-62. doi:10.1038/nature03711.

[39] Misu H, Takamura T, Takayama H, Hayashi H, Matsuzawa-Nagata N, Kurita S, et al. A Liver-Derived Secretory Protein, Selenoprotein P, Causes Insulin Resistance. Cell 
Metab 2010;12:483-95. doi:10.1016/j.cmet.2010.09.015.

[40] Wang Q, Sharma VP, Shen H, Xiao Y, Zhu Q, Xiong X, et al. The hepatokine Tsukushi gates energy expenditure via brown fat sympathetic innervation. Nat Metab 2019:1. doi:10.1038/s42255-018-0020-9. 
Figure 1
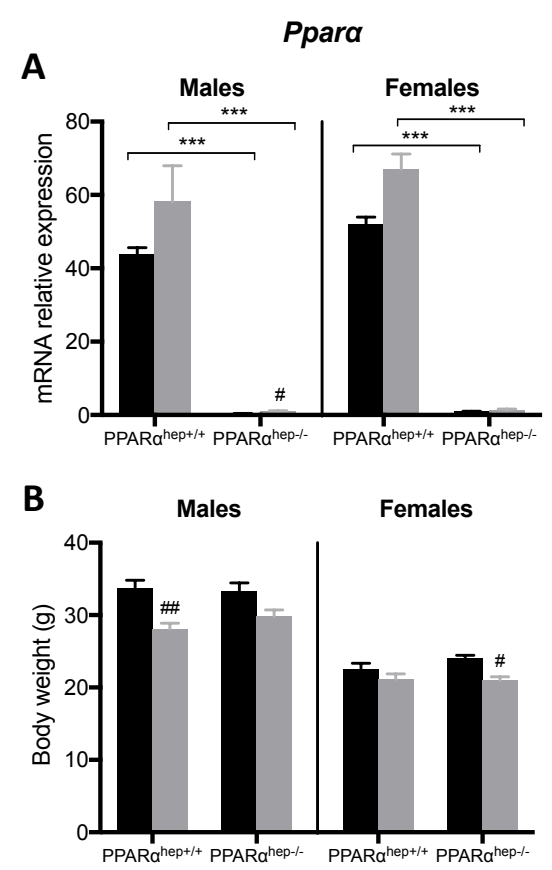

C

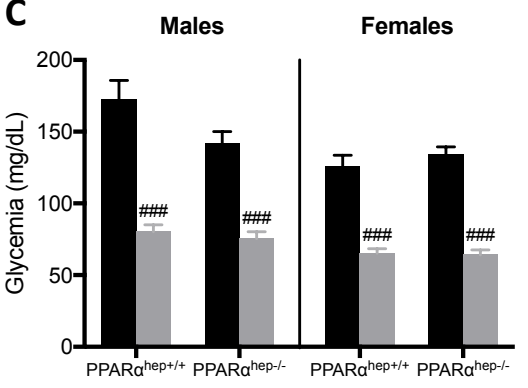

Males

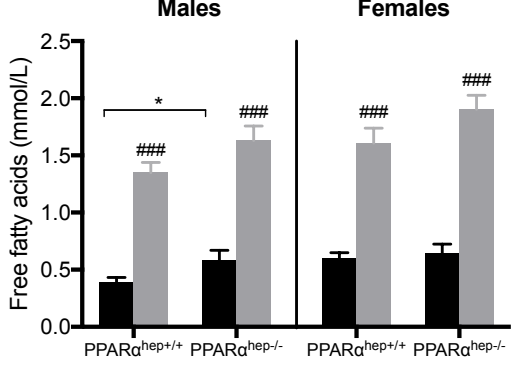

Males

Females

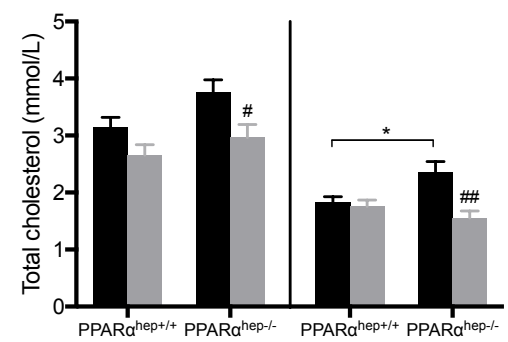

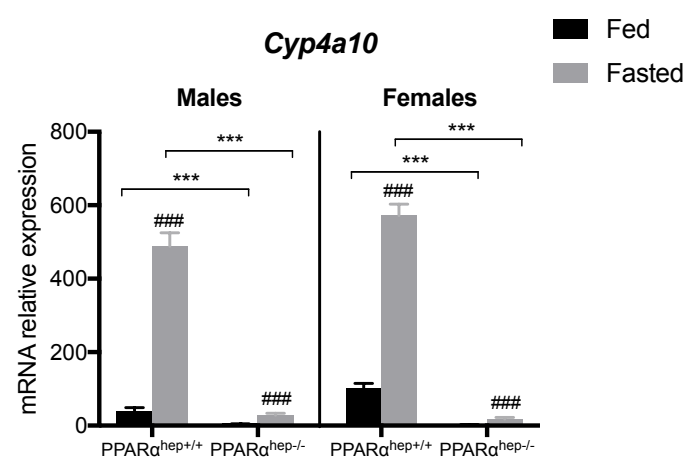
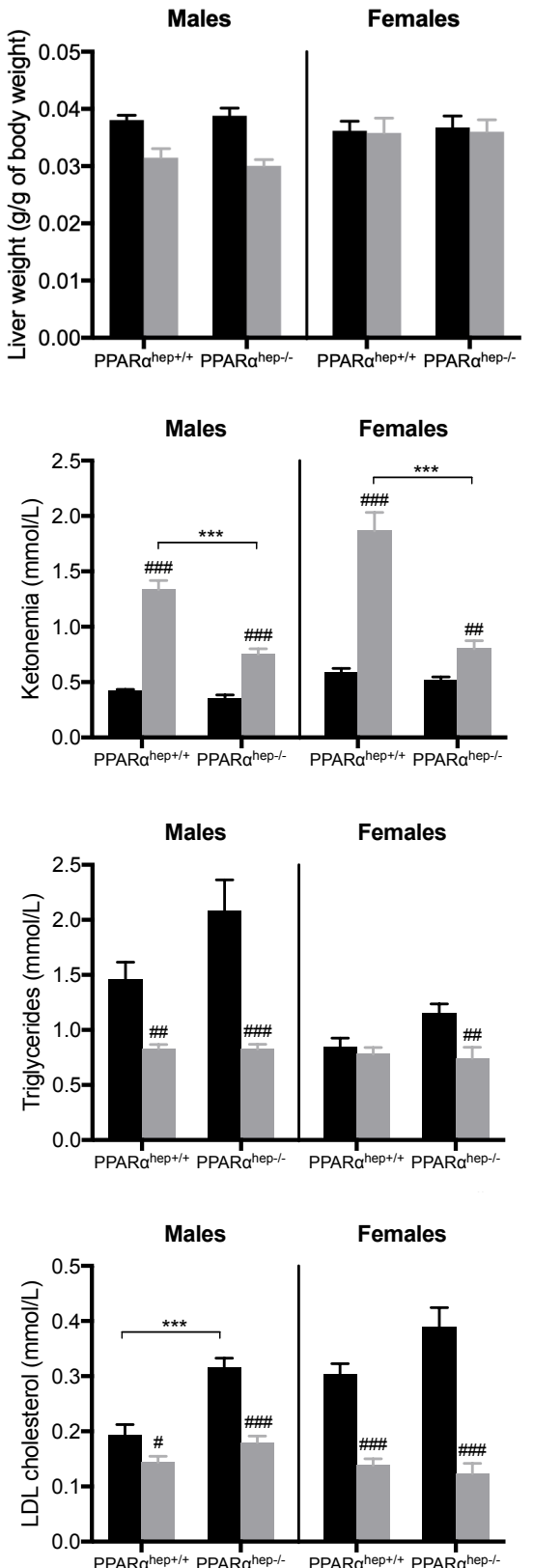

\# nutritional status effect * genotype effect 
Figure 2
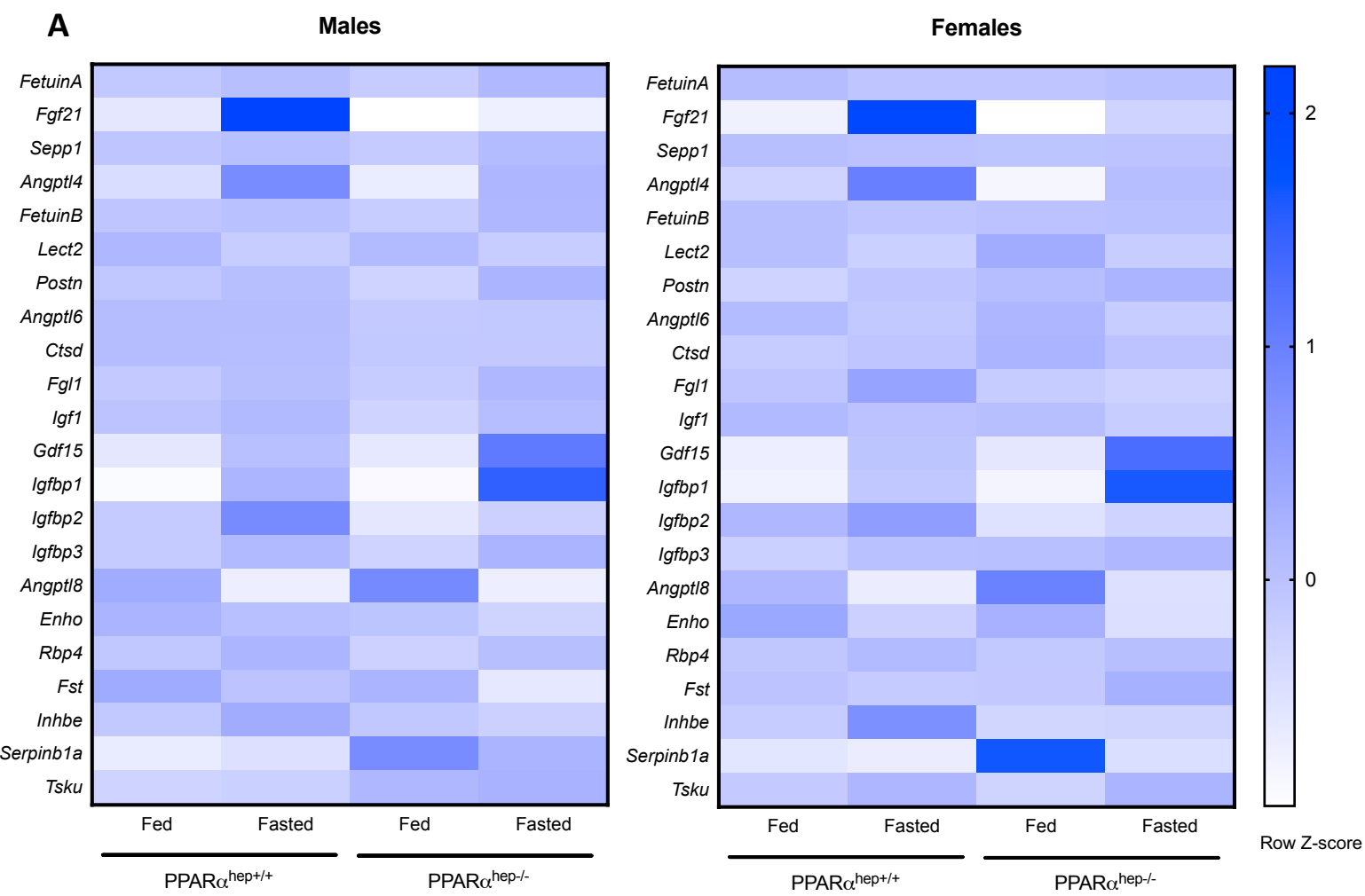

B

Fgf21

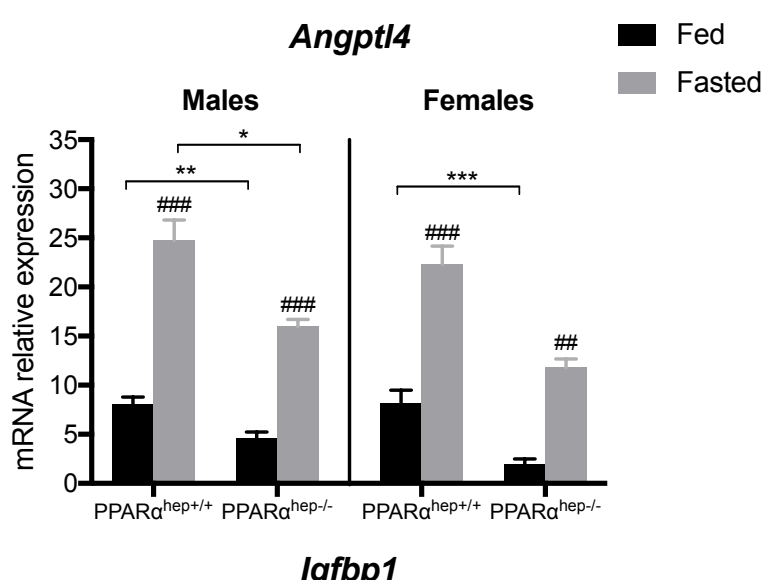

Gdf15
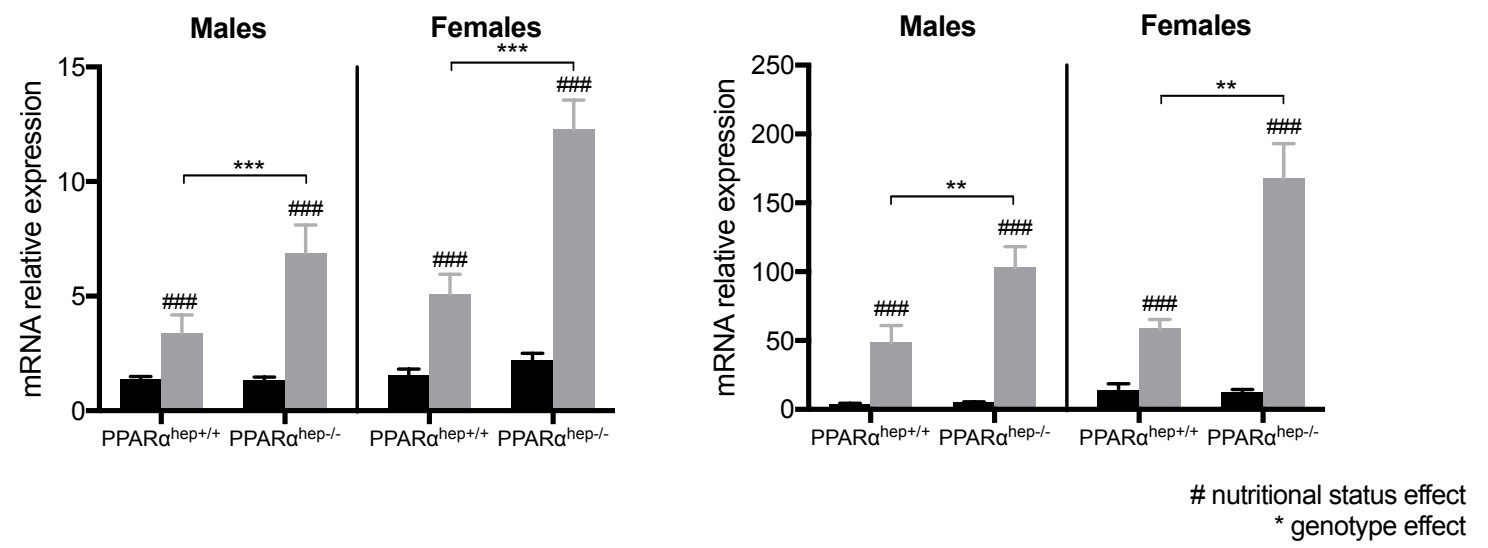
He Hili hili

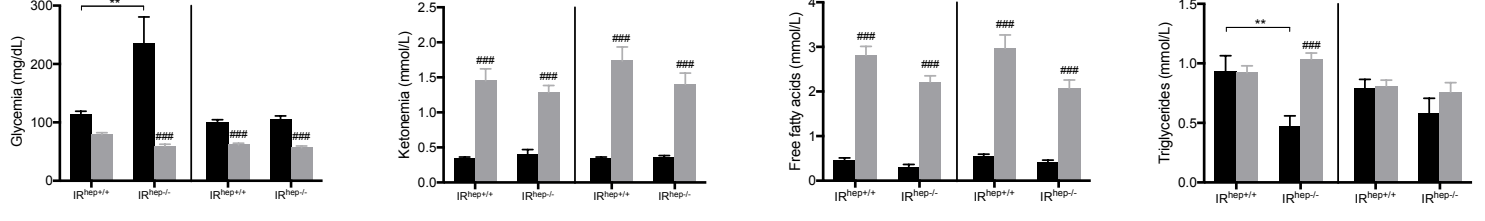

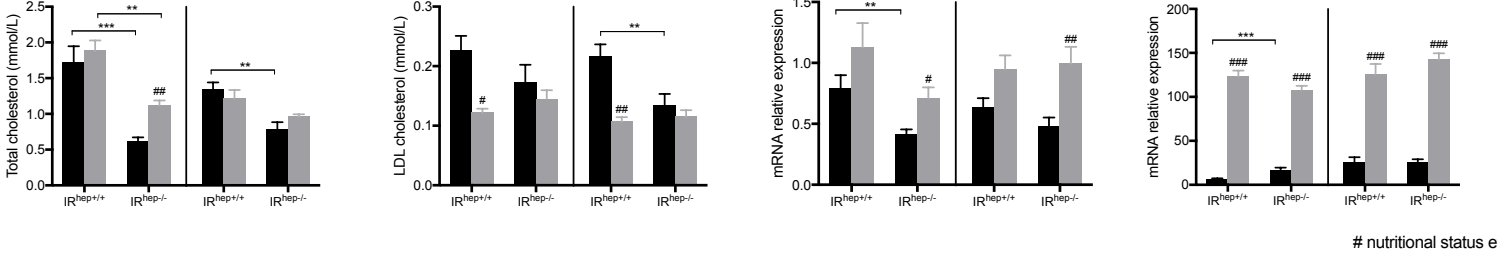


Figure 4
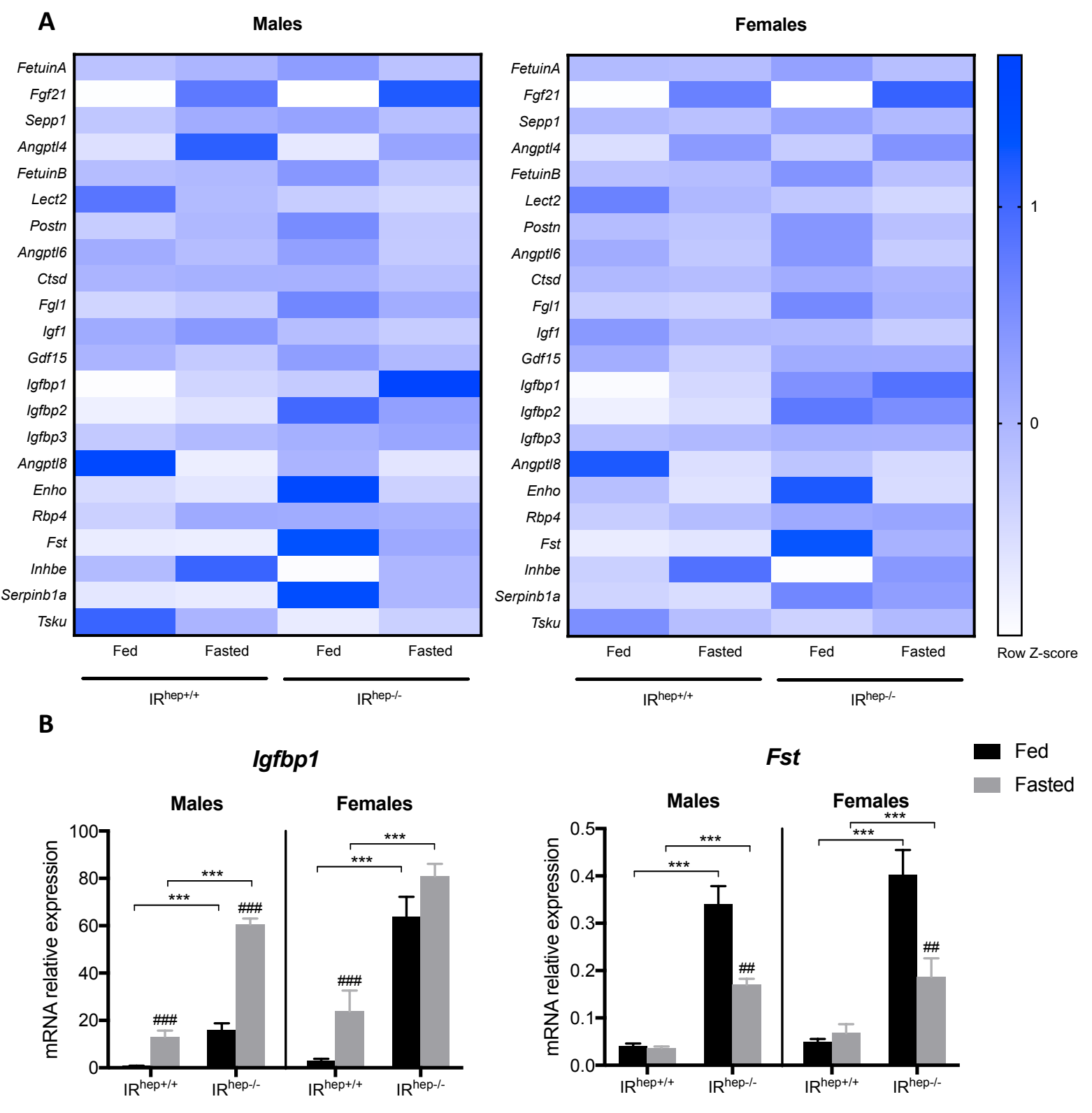

Enho
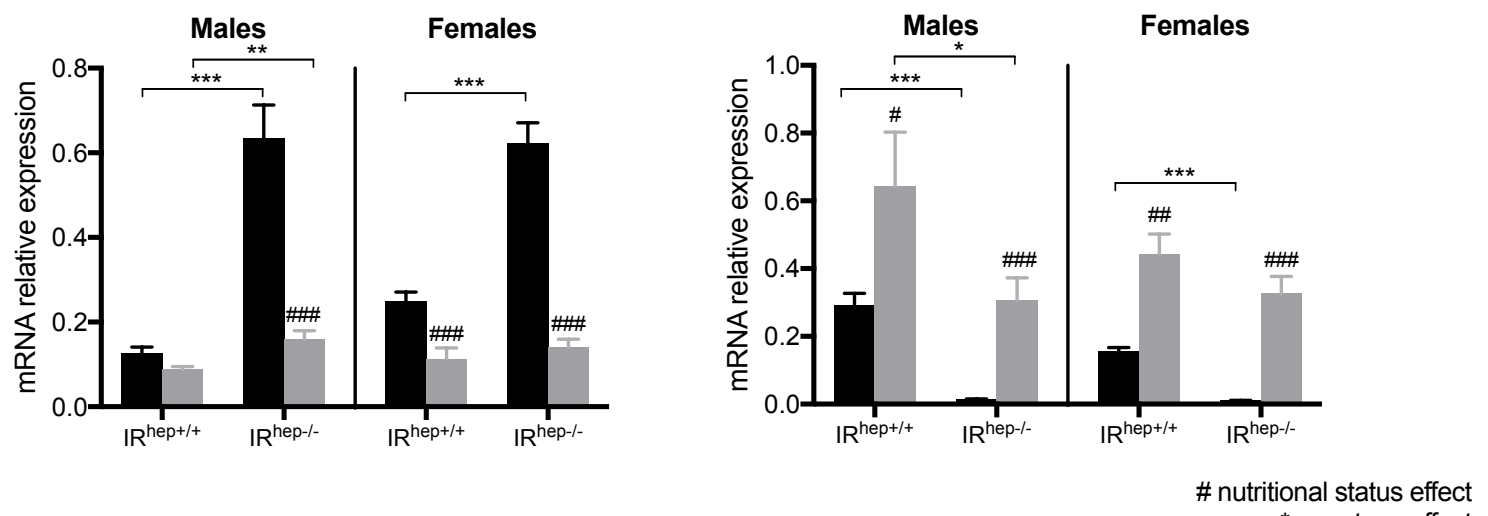

* genotype effect 


\begin{tabular}{|c|c|c|c|}
\hline Gene & NCBI Refseq & Forward primer & Reverse primer \\
\hline Angpt/4 [7] & NM_020581.2 & TTTCCCTGCCCTTCTCTACTTG & TACAGGTACCAAACCACCAGCC \\
\hline Angpt/6 [31] & NM_145154.2 & GAATTGCCGCAAACCTCACT & ATGGCCGTCACCTCTCACAG \\
\hline Angpt/8 [32] & NM_001080940.1 & CCCACCAAGAATTTGAGACCTT & ACTGTTGCTGCTCTGCCATCT \\
\hline Ctsd [33] & NM_009983 & CTTCGTCCTCCTTCGCGATTAT & GTCCGACGGATAGATGTGAACTT \\
\hline Cyp4a10 & NM_010011 & TCCAGCAGTTCCCATCACCT & TTGCTTCCCCAGAACCATCT \\
\hline Enho [6] & NM_027147 & ACCGGGCTCAACTCAGGC & TGGCTGTCCTGTCCACACAC \\
\hline Fasn & NM_007988 & AGTCAGCTATGAAGCAATTGTGGA & CACCCAGACGCCAGTGTTC \\
\hline Fetuina $[8]$ & NM_013465 & ATCGACAAAGTCAAGGTGTGGTCT & TGTCAACTTCCATCTCATACACCACT \\
\hline Fetuinb [9] & NM_021564 & CTCGTCAAAGTCACCAAGGCTAT & CACATAGTAAGCAGGGCCAGAC \\
\hline$F g / 1[10]$ & NM_145594.2 & TGCAAACCTGAACGGTGTTTAC & TTCAAGGAATACCACCACCCA \\
\hline Fgf21 [34] & NM_020013.4 & AAAGCCTCTAGGTTTCTTTGCCA & CCTCAGGATCAAAGTGAGGCG \\
\hline Fst [12] & NM_008046.2 & TGCTGCTACTCTGCCAGTTCAT & САСTCTTCCTTGCTCAGTTCTGTC \\
\hline Gdf15 [35] & NM_011819 & GCTGTCCGGATACTCAGTCCA & TTGACGCGGAGTAGCAGCT \\
\hline $\operatorname{lgf1}[36]$ & NM_0105124 & GATCTGCCTCTGTGACTTCTTGAA & CAGGTAGAAGAGGTGTGAAGACGA \\
\hline lgfbp1 [36] & NM_008341.4 & СCTGCCAACGAGAACTCTAT & AGGGATTTTCTTTCCACTCC \\
\hline lgfbp2 [36] & NM_008342 & GCATGGCCGGTACAACCTTA & GCTGTCCGTTCAGAGACATCTT \\
\hline $\operatorname{lgfbp3}[36]$ & NM_008343 & CAGGCAGCCTAAGCACCTAC & CTCCTCGGACTCACTGATGTTTC \\
\hline Inhbe [28] & NM_008382.3 & TCAGCTTTGCTACCATCATAGACA & CATGGAGCGGTAGGTTGAAGT \\
\hline Lect2 [11] & NM_010702 & GTGGACAGTACTCTGCTCAAA & TCCCAGTGAATGGTGCATAC \\
\hline Ppara & NM_011144 & СCCTGTTTGTGGCTGCTATAATTT & GGGAAGAGGAAGGTGTCATCTG \\
\hline Ppara (genotyping) & NM_011144 & GTACCACTACGGAGTTC & GAATAGTTCGCCGAAAG \\
\hline Postn [37] & NM_015784 & GAATGCTGCCCTGGCTATATGA & AATGCCCAGCGTGCCATAAA \\
\hline Rbp4 [38] & NM_011255 & GCCAAGTTCAAGATGAAGTACTGG & TGTCGTAGTCCGTGTCGATGA \\
\hline Sepp1[39] & NM_009155 & AAGATCGCTTACTGTGAGGAGAGG & GCTGAGGTCACAGTTTTACAGAAGTC \\
\hline Serpinb1a [25] & NM_025429 & GGACGAGTCCACGGGTCTTA & AGTTTGACGTGGACATCAATGAATTC \\
\hline Tsku [40] & NM_001168541 & CCGGTCTAACAGATTTCACGTGT & CAGCAGGAACAGAGAGCACAG \\
\hline$T b p$ & NM_013684 & ACTTCGTGCAAGAAATGCTGAA & GCAGTTGTCCGTGGCTCTCT \\
\hline
\end{tabular}

\section{Supplementary Table 1}

Oligonucleotide sequences for real-time PCR. 


\section{Supplementary Figure 1}
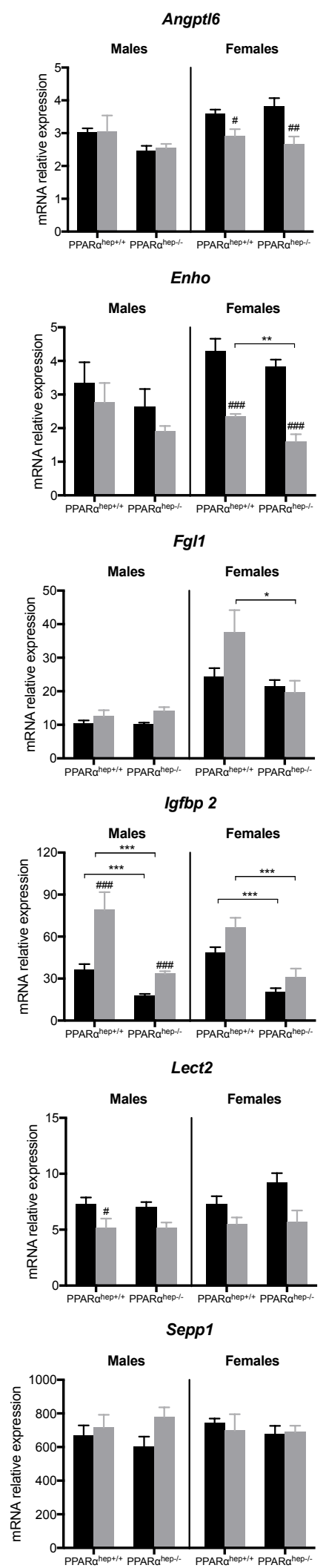

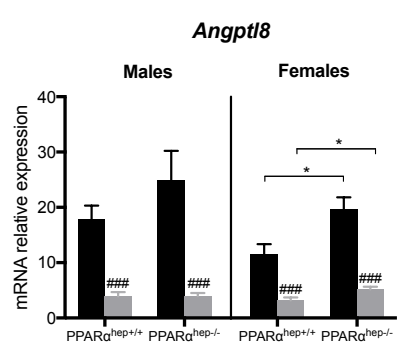

Fetuina
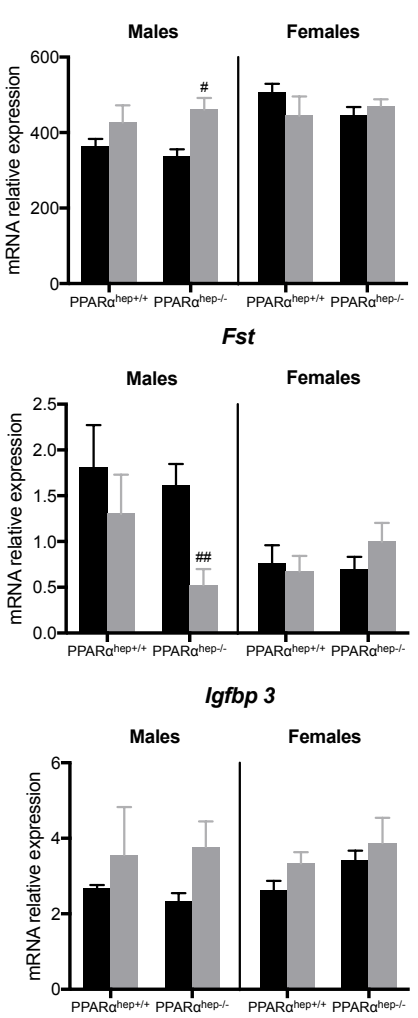

Postn

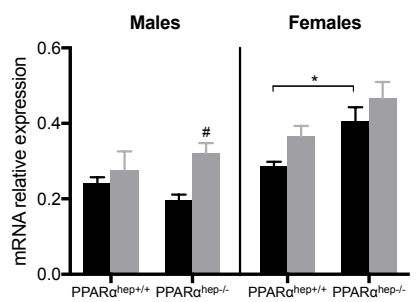

Serpinb1a

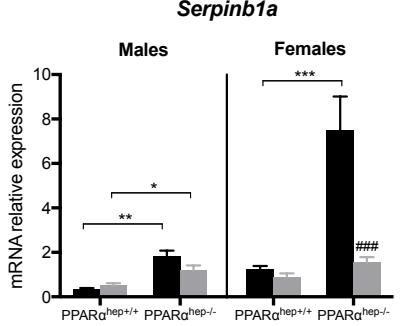

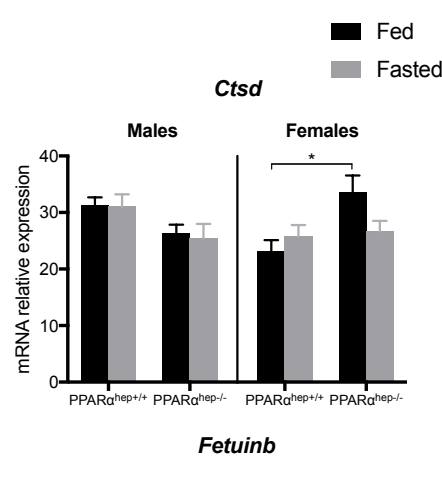

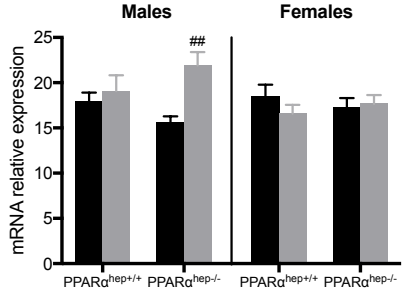

Igf1
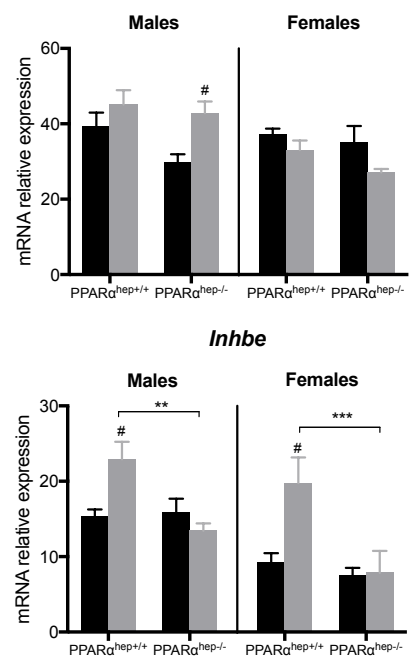

Rbp4
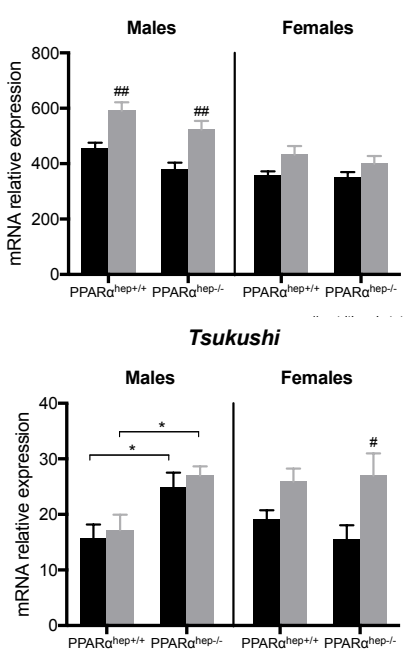
Supplementary Figure 2
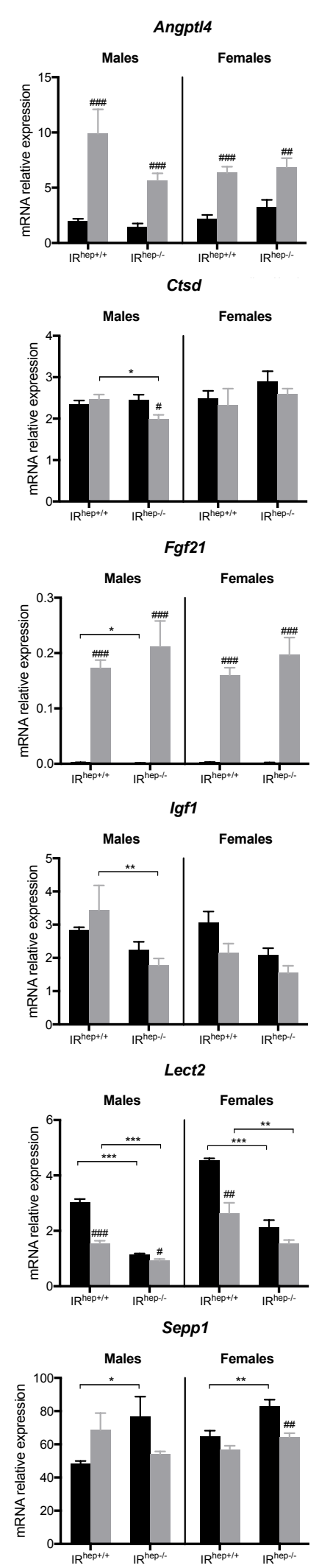
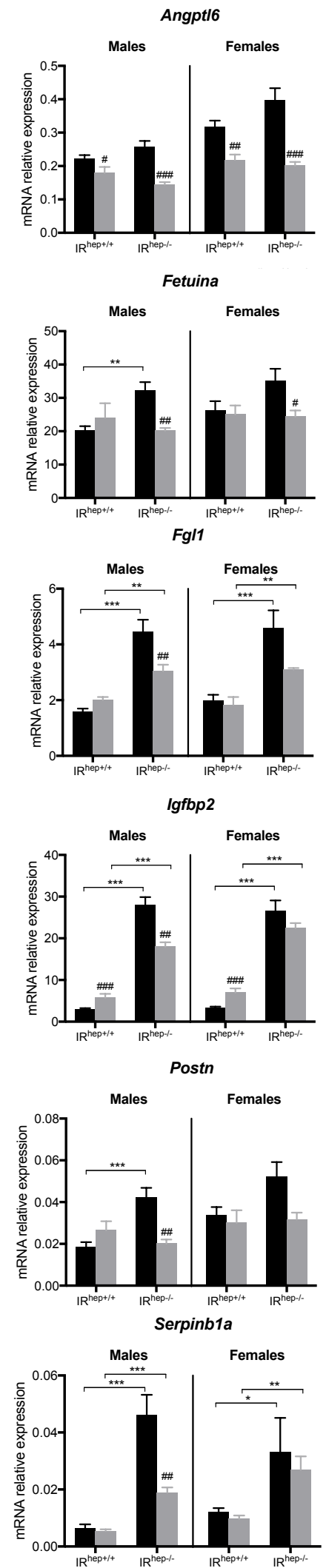
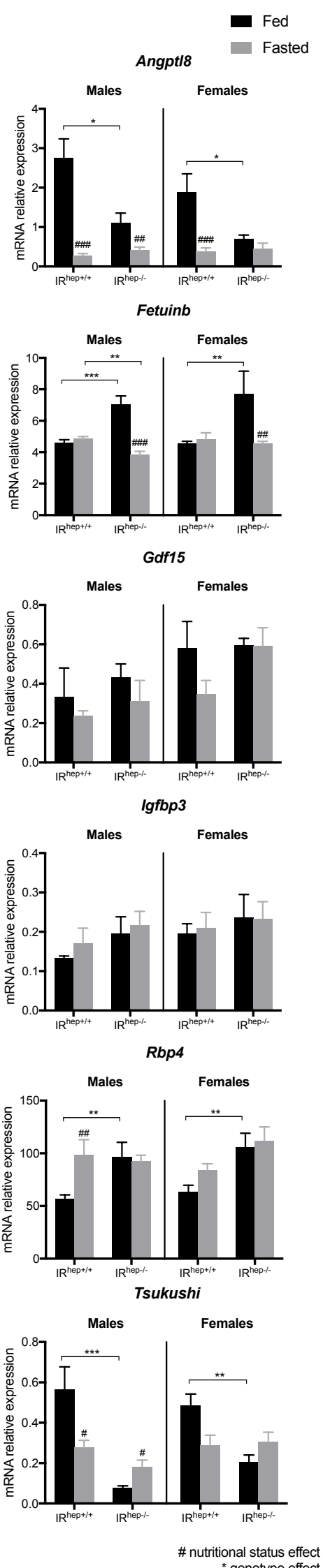
